\title{
Sensitivity of immunoperoxidase and immunofluorescence staining for detecting chlamydia in conjunctival scrapings and in cell culture
}

\author{
R. M. WOODLAND, H. EL-SHEIKH, S. DAROUGAR, AND S. SQUIRES ${ }^{1}$
}

From the Virus Laboratory, Department of Clinical Ophthalmology, Institute of Ophthalmology, Judd Street, London and ${ }^{1}$ May and Baker Limited, Dagenham, Essex, UK

SUMMARY The sensitivities of Giemsa, immunofluorescence, and immunoperoxidase staining for the detection of Chlamydia psittaci inclusions in conjunctival scrapings and in irradiated McCoy cell monolayers were compared. Conjunctival specimens were obtained from a cat colony in which a trachoma-like disease, feline chlamydial keratoconjunctivitis, was endemic. The two immunochemical techniques were found to be of equal sensitivity and $50 \%$ to $100 \%$ more sensitive than Giemsa stain. Permanent preparations of immunoperoxidase stained material can be made and can be read using a simple light microscope. These features make the technique more useful than immunofluorescence staining, which gives temporary preparations that must be examined with a specialised fluorescence microscope.

The fluorescent antibody staining technique has been shown to be more sensitive than Giemsa staining for the detection of chlamydial inclusions in ocular and genital scrapings (Sowa et al., 1971; Hanna, 1968; Nichols et al., 1967; Darougar et al., 1971a).

The immunoperoxidase staining technique (Sternberger et al., 1970) has been used to demonstrate the presence of viral antigens in infected cell cultures and in other specimens (Kurstak et al., 1975), and to study the development cycle of Chlamydia psittaci in peritoneal macrophages of infected mice (Mields et al., 1974).

In this study, feline chlamydial keratoconjunctivitis specimens were used to compare immunoperoxidase staining with immunofluorescence and Giemsa staining, for the detection of chlamydial inclusions in conjunctival scrapings and in cell culture.

\section{Material and methods}

SOURCE OF SPECIMENS

Domestic cats, aged 4 to 8 months, from the animal breeding section at May and Baker Limited, Dagenham, Essex were investigated for infection by the feline chlamydial keratoconjunctivitis (FKC) agent, C. psittaci, which was endemic in the colony.

Received for publication 26 January 1978
COLLECTION AND STORAGE OF SPECIMENS

\section{Conjunctival scrapings}

The conjunctivae of cats were anaesthetised with three to four drops of Jocaine (Darougar et al., 1971b). Conjunctival scrapings were collected using sterile aluminium scrapers, which were flattened at both ends. The collected material was spread thinly and evenly within $6 \mathrm{~mm}$ diameter areas scratched on clean glass microscope slides, and air-dried before fixation. Specimens for Giemsa staining were fixed in absolute methyl alcohol for 10 minutes at room temperature. Specimens for immunoperoxidase and immunofluorescence staining were fixed in absolute acetone at room temperature for five minutes and stored at $-20^{\circ} \mathrm{C}$.

\section{Conjunctival swabbings}

Using a dry disposable sterile cotton wool swab (Exogen Ltd, Glasgow), the main areas of the conjunctiva, namely, upper and lower tarsus, bulbar and both surfaces of the nictitating membrane, were rubbed firmly three to four times. The swab was broken off into a screw-capped sterile plastic ampoule containing $2 \mathrm{SP}$ transport medium with additional fetal bovine serum $(3 \% \mathrm{v} / \mathrm{v})$ and antibiotics (Gordon et al., 1969). Specimens were transported to the laboratory on solid carbon dioxide and stored at $-70^{\circ} \mathrm{C}$ until cultured. 
INOCULATION OF CELL CULTURES

Conjunctival swabbings were inoculated into irradiated McCoy cell monolayers using the simplified technique described by Darougar et al. (1971c). After incubation for 48 hours at $35^{\circ} \mathrm{C}$ the inoculated monolayers were fixed in absolute methyl alcohol for 10 minutes.

\section{STAINING METHODS}

\section{Giemsa stain}

Conjunctival scrapings and cell monolayers were stained for one hour in Giemsa solution (Gurr's R66 - Searle Diagnostic, High Wycombe, Bucks) diluted $1: 10$ in $\mathrm{pH} 6 \cdot 8$ buffer solution. Subsequently they were rinsed in methyl alcohol followed by $\mathrm{pH} 6.8$ buffer solution, and air-dried.

\section{Immunofluorescence staining}

Conjunctival scrapings and cell monolayers were washed in phosphate-buffered saline $\mathrm{pH}$ 7.3 (PBS), dried, overlaid with a 1:10 dilution of hyperimmunised rabbit antichlamydial serum, and incubated in a humid chamber at $35^{\circ} \mathrm{C}$ for 35 minutes. They were then rinsed in PBS and placed in a stirred bath of PBS for 15 minutes, after which they were air-dried, overlaid with a 1:10 dilution of FITC-conjugated goat anti-rabbit IgG (Microbiological Associates Inc, Bethesda, Maryland, USA), and re-incubated for 30 minutes. Subsequently specimens were again rinsed with PBS, washed for 15 minutes in a stirred bath of PBS containing $0.001 \%$ Evans blue dye as counterstain, airdried, and mounted in buffered glycerol $\mathrm{pH} 8 \cdot 5$.

\section{Immunoperoxidase staining}

In this study the peroxidase-antiperoxidase method (Sternberger et al., 1970) was used. Conjunctival scrapings and cell monolayers were washed in PBS, air-dried, and overlaid with a 1:10 dilution of hyperimmunised rabbit antichlamydial serum. After incubation in a humid chamber at $35^{\circ} \mathrm{C}$ for 30 minutes they were rinsed in PBS and washed in a stirred bath of PBS for 15 minutes, dried, overlaid with a 1:10 dilution of swine anti-rabbit serum (Nordic Immunological Laboratories, Maidenhead, Berks), and re-incubated for 30 minutes. The scrapings and monolayers were again washed and dried as above, overlaid with a 1:10 dilution of a soluble complex of horseradish peroxidase and rabbit antihorseradish peroxidase (PAP-DAKO Immunoglobulins, Mercia Diagnostics Ltd, Watford, Herts) re-incubated for 30 minutes, washed, and dried. Finally, the specimens were immersed for 10 minutes in a freshly prepared solution of $3,3^{\prime}$ diaminobenzidine tetrahydrochloride $(0.05 \% \mathrm{w} / \mathrm{v})$ and hydrogen peroxide $(0.01 \% \mathrm{v} / \mathrm{v})$ in PBS, producing a brown insoluble reaction product at the sites of peroxidase activity. Conjunctival scrapings were counterstained with $1 \%$ methyl green solution. Stained preparations were air-dried and mounted in a permanent mounting medium (Gurr's Uvinert-Searle Diagnostic).

Immunofluorescence-stained conjunctival scrapings were restained by immunoperoxidase. After $\stackrel{\mathbb{D}}{\Omega}$ examination they were incubated for 30 minutes at $\nRightarrow$ $35^{\circ} \mathrm{C}$ with 1:10 PAP, washed, immersed in $3,3^{\prime} \vec{\circ}$ diaminobenzidine tetrahydrochloride and hydrogen peroxide solution, and counterstained as above.

\section{EXAMINATION OF STAINED PREPARATIONS} Immunofluorescence-stained preparations were examined using a Zeiss Standard Fluorescence Microscope fitted with an HBO 200 mercury vapour lamp and dark ground condenser. Exciter filter BG12 and barrier filters 50 and 44 were used.

Giemsa- and immunoperoxidase-stained preparations were examined by conventional bright field light microscopy.

Conjunctival scrapings were examined at $\times 320$ magnification. The presence or absence of inclusion bodies in the entire specimen was noted, and the number of inclusions seen in 500 epithelial cells was recorded. Scrapings containing fewer than $50 \mathrm{~g}$ epithelial cells were considered 'inadequate' an were excluded from the study.

Cell monolayers were examined at $\times 200$ magnification, and the number of inclusion bodies seen in the entire monolayer was counted. Where large numbers of inclusion bodies were present, the total number was estimated from the number seen in 50 microscopic fields (about $12 \%$ of the monolayer).

STATISTICS

Paired sample $t$ tests were used for comparison of the results.

\section{Results}

CONJUNCTIVAL SCRAPINGS

Three conjunctival scrapings, for Giemsa, immunofluorescence, and immunoperoxidase staining, were obtained from each of 56 eyes. These were coded for unbiased evaluation. The numbers of positive scrapings and the numbers of inclusions seen with each staining method are shown in Table 1. The sensitivity of Giemsa staining was significantly less than immunofluorescence or immunoperoxidase staining $(\mathrm{P}<0.01)$. There was no significant difference between the sensitivities of immunofluorescence and immunoperoxidase. After examination all immunofluorescence-stained specimens were restained using PAP. Structures identified as inclusions by immunofluorescence could be clearly 
Table 1 Comparison of staining methods for detection of inclusions in 56 cat conjunctival scrapings

\begin{tabular}{lccl}
\hline & Giemsa & $\begin{array}{l}\text { Immunofluores- } \\
\text { cence }\end{array}$ & $\begin{array}{l}\text { Immunoperoxi- } \\
\text { dase }\end{array}$ \\
\hline $\begin{array}{l}\text { Number of } \\
\text { positives }\end{array}$ & $31(55.4 \%)$ & $41(73.2 \%)$ & $42(75 \%)$ \\
$\begin{array}{l}\text { Average number } \\
\text { of inclusions per } \\
500 \text { epithelial cells }\end{array}$ & 3.7 & 5.6 & 5.9 \\
\hline
\end{tabular}

seen stained by immunoperoxidase (Figs 1 and 2).

Common artefacts seen in immunoperoxidasestained scrapings were pigment granules (Fig. 3) and brown-staining erythrocytes.

CELl CULTURE

Four laboratory isolates of feline keratoconjunctivitis agent (FKC/Ps/1/IOL-2/0, FKC/Ps/1/ IOL-457/0, FKC/Ps/1/IOL-562/0, and FKC/Ps/1/ IOL-1333/0) were used. Two dilutions of each were prepared and each was inoculated into six monolayers. Two monolayers were stained by each of the three methods. The numbers of inclusions seen with immunoperoxidase were not significantly different from the numbers seen with immunofluorescence $(0.9>P>0.7)$, but the numbers of inclusions seen with Giemsa were significantly less $(P<0.01)$ (Table 2).

Table 2 Comparison of staining methods for detection of inclusions in irradiated McCoy cell monolayers inoculated with feline keratoconjunctivitis agent

\begin{tabular}{|c|c|c|c|c|c|c|c|}
\hline \multirow[t]{2}{*}{ Isolate } & \multirow[t]{2}{*}{ Dilution } & \multicolumn{6}{|c|}{ Number of inclusions } \\
\hline & & \multicolumn{2}{|c|}{ Giemsa } & \multicolumn{2}{|c|}{$\begin{array}{l}\text { Immunofluores- } \\
\text { cence }\end{array}$} & \multicolumn{2}{|c|}{$\begin{array}{l}\text { Immunoperoxi } \\
\text { dase }\end{array}$} \\
\hline \multirow[t]{2}{*}{2} & $10^{-4}$ & 20 & $\times 10^{2}$ & 23 & $\times 10^{2}$ & 27 & $\times 10^{2}$ \\
\hline & $10^{-5}$ & $2 \cdot 1$ & $\times 10^{2}$ & 4.9 & $\times 10^{2}$ & $3 \cdot 7$ & $\times 10^{2}$ \\
\hline \multirow[t]{2}{*}{562} & $10^{-4}$ & $2 \cdot 5$ & $\times 10^{2}$ & $4 \cdot 1$ & $\times 10^{2}$ & $4 \cdot 5$ & $\times 10^{2}$ \\
\hline & $10^{-5}$ & 0.19 & $\times 10^{2}$ & 0.34 & $\times 10^{2}$ & 0.30 & $\times 10^{2}$ \\
\hline \multirow[t]{2}{*}{457} & $10^{-4}$ & 8.0 & $\times 10^{2}$ & 7.8 & $\times 10^{2}$ & 8.7 & $\times 10^{2}$ \\
\hline & $10^{-5}$ & 0.38 & $\times 10^{2}$ & 0.59 & $\times 10^{2}$ & 0.54 & $\times 10^{2}$ \\
\hline \multirow[t]{2}{*}{1333} & $10^{-4}$ & $2 \cdot 3$ & $\times 10^{2}$ & 3.7 & $\times 10^{2}$ & $4 \cdot 3$ & $\times 10^{2}$ \\
\hline & $10^{-5}$ & 0.16 & $\times 10^{2}$ & 0.29 & $\times 10^{2}$ & 0.26 & $5 \times 10^{2}$ \\
\hline \multicolumn{2}{|c|}{ Relative percentag } & & 100 & & 161 & & 156 \\
\hline
\end{tabular}

Subsequently, 50 conjunctival swabbings collected from the eyes of 34 cats were each inoculated into two irradiated McCoy cell monolayers. After incubation and fixation, one monolayer from each specimen was stained by immunoperoxidase and the other was stained by Giemsa. Chlamydial inclusions were seen in $38(76 \%)$ of the immunoperoxidasestained monolayers and in $19(38 \%)$ of the Giemsastained monolayers.

\section{Discussion}

In this study, specimens were obtained from cats in a colony in which feline chlamydial keratoconjunctivitis, caused by a $C$. psittaci organism, was endemic. The clinical picture of this disease is very similar to that of human ocular infection with Chlamydia trachomatis, which causes hyperendemic trachoma (Darougar et al., 1977a) or paratrachoma (inclusion conjunctivitis, TRIC punctate keratoconjunctivitis of sexually transmitted origin) (Jones, 1975). It was therefore considered appropriate to use cats as a source of infected material for this investigation.

The results indicate that immunoperoxidase staining is as sensitive as immunofluorescence for the detection of chlamydial inclusions and that both of these immunochemical methods are more sensitive than Giemsa staining.

Extreme care is needed in reading immunofluorescence and immunoperoxidase-stained conjunctival scrapings so that only those intracytoplasmic structures which morphologically resemble inclusions are scored as positive. The use of counterstains facilitates the identification and delineation of epithelial cells. Erythrocytes, which contain endogenous peroxidase, stain the same brown colour as inclusion bodies in immunoperoxidase-stained scrapings, but are easily distinguished morphologically. Pigment granules, which are present in many conjunctival cells, can be recognised by their larger size, deeper colour, and greenish tint (Fig. 3). Pigment-containing cells are often seen in conjunctival scrapings from humans, particularly in those from coloured patients.

In cell culture, Giemsa-stained $C$. psittaci inclusions cannot be detected reliably by dark-ground illumination, a method which is extremely sensitive for $C$. trachomatis inclusions, and more laborious bright field examination is therefore needed. In this study the poor detection rates for Giemsa compared to the immunochemical techniques indicates the insensitivity of the former method for detecting C. psittaci inclusions. In cell cultures inoculated with C. trachomatis agents no marked differences are observed between Giemsa staining and immunofluorescence staining for the detection of inclusions. However, immunochemical staining methods provide a means by which smaller inclusions can be detected in tissue culture cells, thus reducing the time of incubation needed for a test (Darougar et al., 1977b; Thomas et al., 1977).

In general, the contrast of immunofluorescencestained inclusions against the background was better than for immunoperoxidase-stained inclusions, making examination easier by the former method. However, immunoperoxidase-stained specimens do 


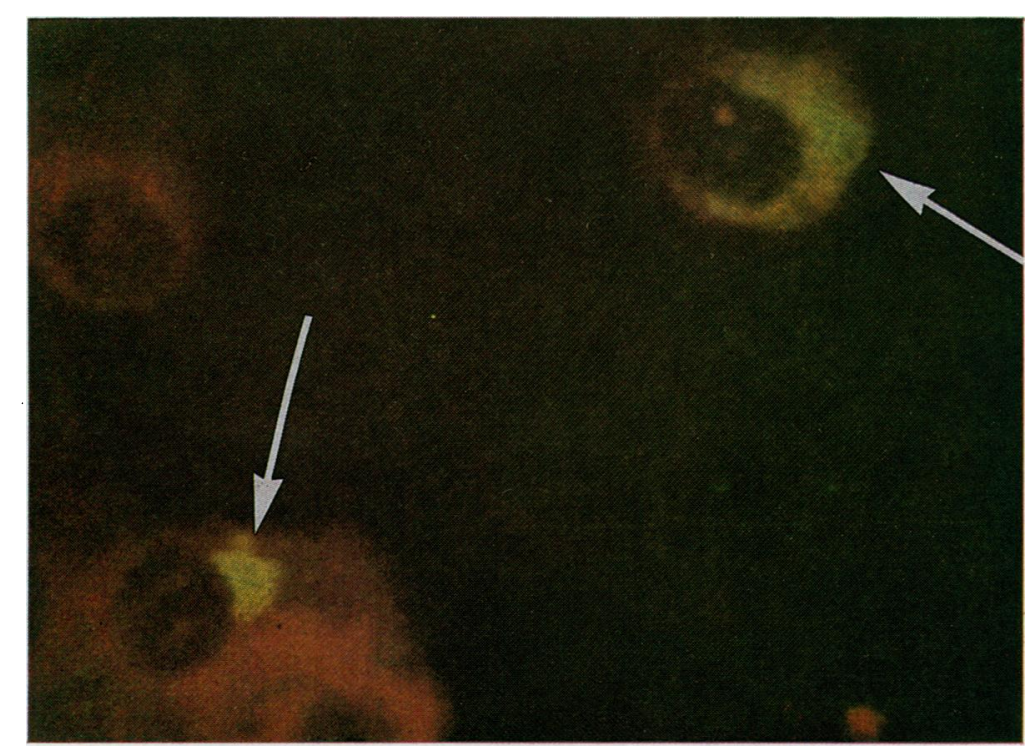

Fig. 1 Immunofluorescent stained cat conjunctival scraping showing brightly fluorescing chlamydial inclusion bodies. ( $\times 1400)$

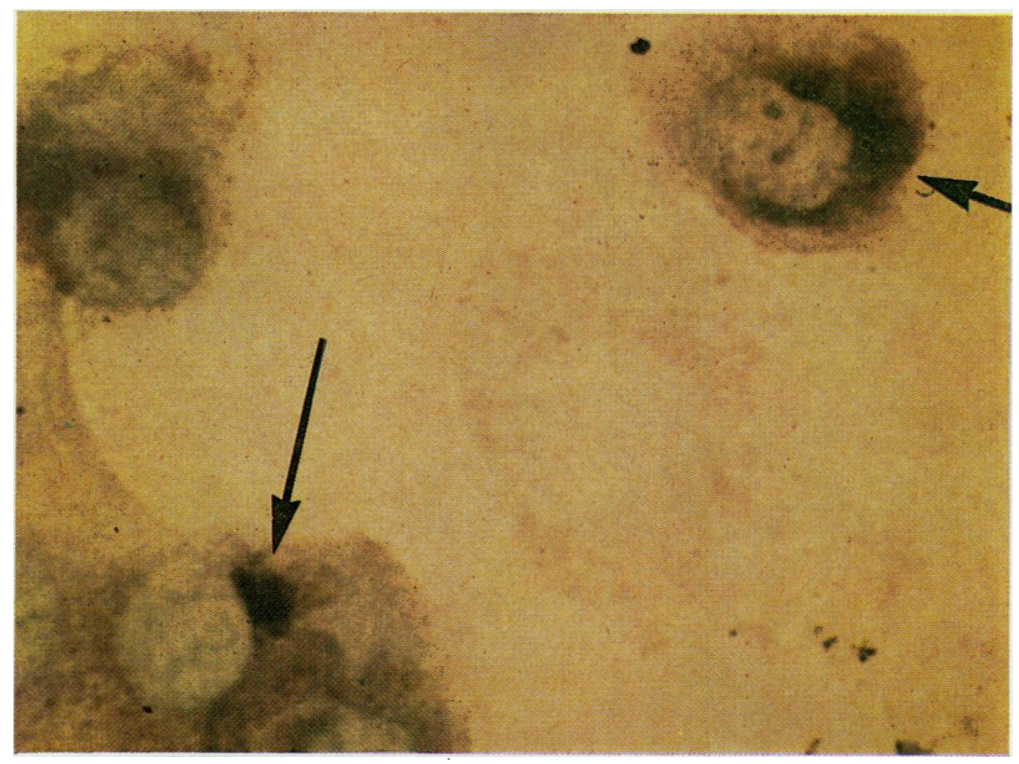

Fig. 2 Immunoperoxidase stained cat conjunctival scraping. The inclusions shown in Fig. 1 have been restained dark brown by the PAP method. ( $\times 1400)$

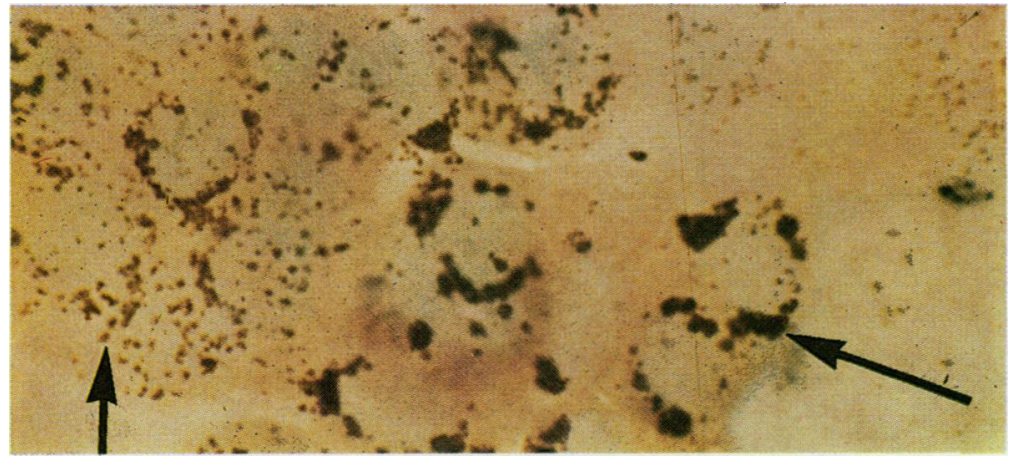

Fig. 3 Immunoperoxidase stained cat conjunctival scraping showing pigment granules in epithelial cells. ( $\times 1400)$ 
not deteriorate as do immunofluorescence-stained specimens and can be stored for examination at leisure and for further reference. Additionally, immunoperoxidase-stained specimens can be examined by normal light microscopy, which may recommend the technique for laboratories lacking expensive fluorescence microscopy equipment. The use of the PAP staining method in this study provided a method whereby immunofluorescence-stained specimens could be restained, but an indirect immunoperoxidase staining technique may be more practical for general use. Studies are in progress to evaluate the use of the indirect method for the staining of specimens from humans.

We are indebted to Mrs Cumberland and her colleagues at May and Baker Limited for the provision and care of animals, and to Professor Barrie R. Jones and Dr McFadzean for their support.

This work was financially supported by grants from an anonymous donor, the Department of Health and Social Security, and the World Health Organization.

\section{References}

Darougar, S., Dwyer, R. St. C., Treharne, J. D., Harper, I. A., Garland, J. A., and Jones, B. R. (1971a). A comparison of laboratory methods of diagnosis of chlamydial infection. In Trachoma and Related Disorders Caused by Chlamydial Agents (International Congress Series, 223) edited by R. L. Nichols, pp. 445-460. Excerpta Medica, Amsterdam.

Darougar, S., Kinnison, J. R., and Jones, B. R. (1971c). Simplified irradiated McCoy cell culture for isolation of Chlamydiae. In Trachoma and Related Disorders Caused by Chlamydial Agents, edited by R. L. Nichols, pp. 63-70. Excerpta Medica, Amsterdam.

Darougar, S., Monnickendam, M. A., El-Sheikh, H., Treharne, J. D., Woodland, R. M., and Jones, B. R. (1977a). Animal models for the study of chlamydial infections of the eye and genital tract. In Nongonococcal Urethritis and Related Infections, edited by D. Hobson and K. K. Holmes, pp. 186-198. American Society for Microbiology, Washington, DC.

Darougar, S., Treharne, J. D., Dwyer, R. St. C., Kinnison, J. R., and Jones, B. R. (1971b). Isolation of TRIC agent (Chlamydia) in irradiated McCoy cell culture from endemic trachoma in field studies in Iran. British Journal of Ophthalmology, 55, 591-599.
Darougar, S. Woodland, R. M., Forsey, T., Cubitt, S., Allami, J., and Jones, B. R. (1977b). Isolation of Chlamydia from ocular infections. In Nongonococcal Urethritis and Related Infections, edited by D. Hobson and K. K. Holmes, pp. 295-298. American Society for Microbiology, Washington, DC.

Gordon, F. B., Harper, I. A., Quan, A. L., Treharne, J. D., Dwyer, R. St. C., and Garland, J. A. (1969). Detection of Chlamydia (Bedsonia) in certain infections of man. I. Laboratory procedures: comparison of yolk sac and cell culture for detection and isolation. Journal of Infectious Diseases, 120, 451-462.

Hanna, L. (1968). An evaluation of the fluorescent antibody technic in the diagnosis of trachoma and inclusion conjunctivitis. Revue Internationale de Trachome, 45, 345-359.

Jones, B. R. (1975). The prevention of blindness from trachoma. Transactions of the Ophthalmological Societies of the United Kingdom, 95, 16-33.

Kurstak, E., Tijssen, P., Kurstak, C., and Morisset, R. (1975). Progress in the application of new immunoenzymatic methods in virology. Annals of the New York Academy of Sciences, 254, 369-384.

Mields, W., Hentschke, J., Becker, W., and Teufel, P. (1974). Die Immunperoxidase-Methode zum Nachweis von Virus- und Chlamydien-antigenen. II. Darstellung des Entwicklungszyklus von Chlamydia psittaci in Peritonealmakrophagen infizierter Mäuse. Zentralblatt für Veterinärmedizin, 21, 48-58.

Nichols, R. L., Bobb, A. A., Haddad, N. A., and McComb, D. E. (1967). Immunofluorescent studies of the microbiologic epidemiology of trachoma in Saudi Arabia. American Journal of Ophthalmology, 63, 1372-1424.

Sowa, J., Collier, L. H., and Sowa, S. (1971). A comparison of the iodine and fluorescent antibody methods for staining trachoma inclusions in the conjunctiva. Journal of Hygiene, 69, 693-708.

Sternberger, L. A., Hardy, P. H., Jr., Cuculis, J. J., and Meyer, H. G. (1970). The unlabeled antibody enzyme method of immunohistochemistry. Preparation and properties of soluble antigen-antibody complex (horseradish peroxidase-antihorseradish peroxidase) and its use in identification of spirochetes. Journal of Histochemistry and Cytochemistry, 18, 315-333.

Thomas, B. J., Evans, R. T., Hutchinson, G. R., and Taylor-Robinson, D. (1977). Early detection of chlamydial inclusions combining the use of cycloheximide-treated McCoy cells and immunofluorescence staining. Journal of Clinical Microbiology, 6, 285-292.

Requests for reprints to: R. M. Woodland, Virus Laboratory, Institute of Ophthalmology, Judd Street, London WC1H 9QS, UK. 